Communication

\title{
Intracellular Environment Improvement of Mycobacterium neoaurum for Enhancing Androst-1,4-Diene-3,17-Dione Production by Manipulating NADH and Reactive Oxygen Species Levels
}

\author{
Minglong Shao ${ }^{1}$, Youxi Zhao ${ }^{2}$, Yu Liu ${ }^{1}$, Taowei Yang ${ }^{1}$, Meijuan $\mathrm{Xu}^{1}{ }^{1}$, Xian Zhang ${ }^{1}$ and \\ Zhiming Rao ${ }^{1, *}$ \\ 1 The Key Laboratory of Industrial Biotechnology of Ministry of Education, School of Biotechnology, \\ Jiangnan University, Wuxi 214122, China; mlshao@jiangnan.edu.cn (M.S.); LY9527@tom.com (Y.L.); \\ ytw1228@163.com (T.Y.); xumeijuan@jiangnan.edu.cn (M.X.); zxshengwu@126.com (X.Z.) \\ 2 Beijing Key Laboratory of Biomass Waste Resource Utilization, College of Biochemical Engineering, \\ Beijing Union University, Beijing 10023, China; zhaoyouxi@buu.edu.cn \\ * Correspondence: raozhm@jiangnan.edu.cn
}

Received: 22 September 2019; Accepted: 20 October 2019; Published: 25 October 2019

\begin{abstract}
As one of the most significant steroid hormone precursors, androst-1,4-diene-3,17-dione (ADD) could be used to synthesize many valuable hormone drugs. The microbial transformation of sterols to ADD has received extensive attention in recent years. In a previous study, Mycobacterium neoaurum JC-12 was isolated and converted sterols to the major product, ADD. In this work, we enhanced ADD yield by improving the cell intracellular environment. First, we introduced a nicotinamide adenine dinucleotide (NADH) oxidase from Bacillus subtilis to balance the intracellular $\mathrm{NAD}^{+}$availability in order to strengthen the ADD yield. Then, the catalase gene from $M$. neoaurum was also over-expressed to simultaneously scavenge the generated $\mathrm{H}_{2} \mathrm{O}_{2}$ and eliminate its toxic effects on cell growth and sterol transformation. Finally, using a $5 \mathrm{~L}$ fermentor, the recombinant strain JC- $12_{\text {yodC-kat } A}$ produced $9.66 \mathrm{~g} / \mathrm{L}$ ADD, which increased by $80 \%$ when compared with the parent strain. This work shows a promising way to increase the sterol transformation efficiency by regulating the intracellular environment.
\end{abstract}

Keywords: androst-1,4-diene-3,17-dione; intracellular environment; NADH oxidase; catalase; Mycobacterium neoaurum

\section{Introduction}

As one of the well-known androgen steroids, androst-1,4-diene-3,17-dione (ADD) was extensively used as an important precursor for the synthesis of steroid hormone medicines in the pharmaceutical industry [1]. Traditionally, ADD was obtained from natural steroids such as sapogenin and diosgenin using multistep chemical degradation and modification methods. However, the well-established route of sapogenin and diosgenin to ADD has many drawbacks, such as waste of land resources, high-cost processes, relatively low yields, and high pollution [2]. With the awareness of environmental protection, biological technology has become the development tendency and inevitable choice for the steroid medical industry [3,4].

Since the discovery of microbial sterols side-chain degradation to 17-ketosteroids, sterol biotransformation has become a promising alternative way to synthesize valuable steroid intermediates in the pharmaceutical industry [5]. Among all the microorganisms that could 
degrade sterols to steroids, Mycobacterium was known as the most promising ADD producing strain [6]. Owing to the distinguished work of finding sterol metabolism gene clusters in Mycobacterium [7], many works have focused on the identification and characterization of these enzymes recently [8-10]. There have also been some efforts made to improve sterol biotransformation. Wei et al. over-expressed 3-ketosteroid- $\Delta^{1}$-dehydrogenase (KSDD) in M. neoaurum to increase soybean phytosterol bioconversion [11]. Su et al. used cofactor engineering to maintain the balance of redox to promote steroid biotransformation [12]. In our previous study, we used stepwise pathway engineering to strengthen the metabolic flux of the sterols for the improvement of ADD production [13]. However, few articles reported about the intracellular environment of Mycobacterium, which is important for strain growth and sterol biotransformation.

The cell intracellular environment mainly contains adenosine diphosphate (ADP), adenosine triphosphate (ATP), nicotinamide adenine dinucleotides (NADH and $\mathrm{NAD}^{+}$), nicotinamide adenine dinucleotide phosphate (NADPH and $\mathrm{NADP}^{+}$) and reactive oxygen species (ROS) [14]. NADH and $\mathrm{NAD}^{+}$play important roles in cell physiological activities and participate in almost all of the metabolic pathways in industrial strains [15-17]. As it was postulated, the bioconversion equation of $1 \mathrm{~mol} \beta$-sitosterol to ADD was shown: $\beta$-sitosterol $+21 \mathrm{NAD}^{+}+10 \mathrm{FAD}+4 \mathrm{ATP}+7 \mathrm{P}_{\mathrm{i}}+7$ $\mathrm{GDP}+21 \mathrm{H}_{2} \mathrm{O}=\mathrm{ADD}+21 \mathrm{NADH}+10 \mathrm{FADH}_{2}+4 \mathrm{AMP}+7 \mathrm{GTP}+4 \mathrm{PP}_{\mathrm{i}}+21 / 2 \mathrm{CO}_{2}+21 \mathrm{H}^{+}[12,18]$. Therefore, the $\mathrm{NADH} / \mathrm{NAD}^{+}$regeneration and the maintenance of the redox balance are considered as the rate-limiting factors in the steroid synthetic pathway and important factors for the steady state of the cell intracellular environment [12]. As the toxic intermediates for the cell intracellular environment, ROS, including hydrogen peroxide $\left(\mathrm{H}_{2} \mathrm{O}_{2}\right)$ and hydroxyl radicals $(\cdot \mathrm{OH})$, are produced due to the incomplete oxidation during aerobic metabolism [14]. Additionally, $\mathrm{H}_{2} \mathrm{O}_{2}$ generated during the flavin adenine dinucleotide (FAD) regeneration was reported in our previous study [19]. Thus, it is important to decrease the high level of ROS and to maintain the balance of the cell intracellular environment during steroid synthesis.

M. neoaurum JC-12 converting phytosterol to ADD was obtained by mutation in our lab [20]. In this study, we maintained the balance of the cell intracellular environment in M. neoaurum JC-12 to enhance phytosterol conversion efficiency. First, the NADH oxidase (NOX) from Bacillus subtilis [21], was expressed in $M$. neoaurum JC-12 to construct the intracellular $\mathrm{NAD}^{+}$regeneration. Then, catalase catalyzing dismutation of $\mathrm{H}_{2} \mathrm{O}_{2}$ into $\mathrm{H}_{2} \mathrm{O}$ and $\mathrm{O}_{2}$, was expressed to eliminate any toxic effects caused by high ROS level (Figure 1). Finally, the recombinant strain JC-12 yodC-kat $A_{\text {p }}$ produced $9.66 \mathrm{~g} / \mathrm{L}$ ADD on a $5 \mathrm{~L}$ bioreactor, which is 1.8 -fold of the production by parent strain JC-12. This study supplies new insight into maintaining the balance of the cell intracellular environment to improve the production of steroid precursors by sterol biotransformation.

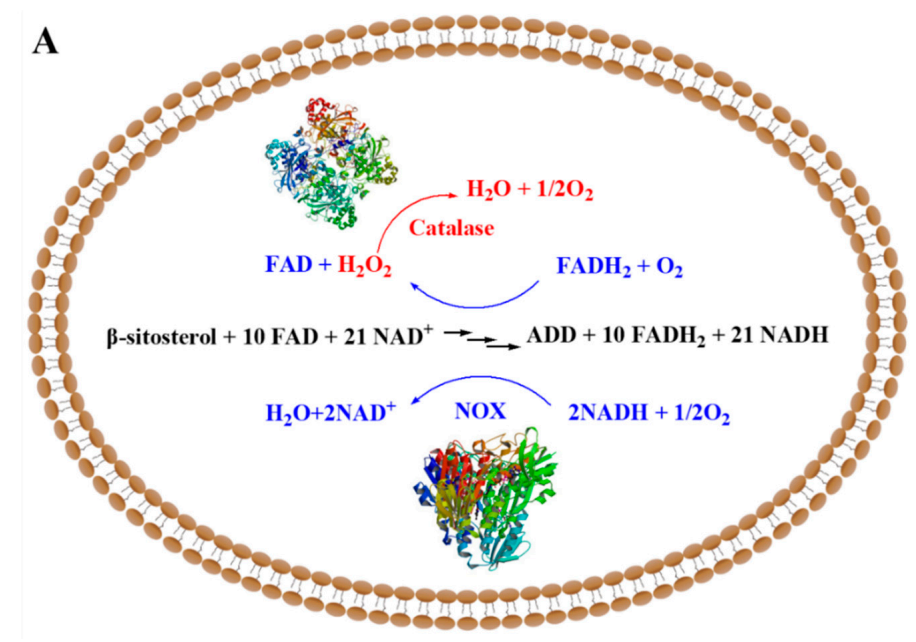

Figure 1. Cont. 


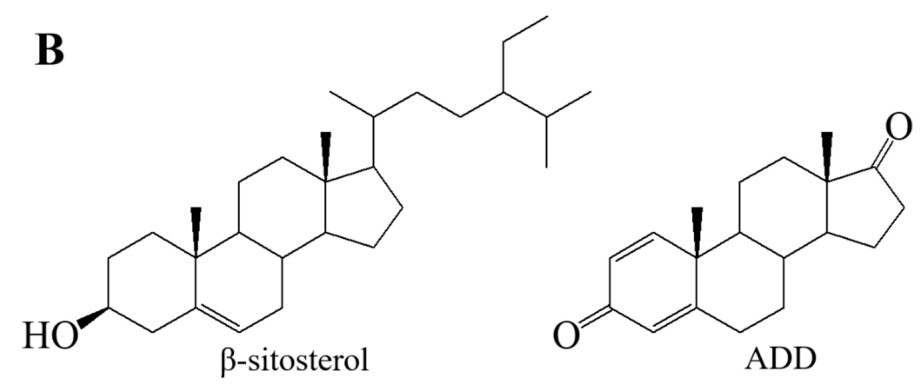

Figure 1. The NOX and catalase were co-expressed to rebalance the cell intracellular environment during biotransformation of sterols to androst-1,4-diene-3,17-dione (ADD) in Mycobacterium neoaurum. (A) sterol biotransformation to ADD; (B) structural formula of $\beta$-sitosterol and ADD.

\section{Results and Discussion}

2.1. The Increase in $N A D^{+}$Availability by Expressing NOX Resulted in an Improved ADD Yield in the NAD ${ }^{+}$ Regeneration System of JC- $12_{\text {yodc }}$

During the phytosterol bioconversion pathway, the intracellular $\mathrm{NAD}^{+}$concentration and availability decreased as the $\mathrm{NAD}^{+}$was largely consumed. Construction of the $\mathrm{NAD}^{+}$regeneration system by over-expressing NOX in engineered JC-12 yodC could enhance the intracellular $\mathrm{NAD}^{+}$pool and further strengthen the sterol metabolic flux. The successful construction of the recombinant strain JC-12 yodC was verified by plasmid extraction and gene sequencing.

As shown in Figure 2A, no difference in biomass was observed between JC-12 2261 and JC-12 yodC, indicating that $M$. neoaurum cell growth was not affected by NOX expression. However, recombinant JC-12 $2_{\text {yod }}$ produced $7.53 \mathrm{~g} / \mathrm{L}$ ADD, which increased by $43 \%$ when compared with JC- $12_{p 261}(5.26 \mathrm{~g} / \mathrm{L})$ at $144 \mathrm{~h}$ (Figure 2B). This result indicates that the functional NOX expression resulted in an increased $\mathrm{NAD}^{+}$availability, which further improved the $\mathrm{NAD}^{+}$-dependent sterols catabolism flux. To explain this phenomenon, the $\mathrm{NADH}$ and $\mathrm{NAD}^{+}$intracellular concentrations were determined. In these two strains, $\mathrm{NAD}^{+}$and NADH intracellular concentrations continuously changed during the phytosterol transformation process (Figure $2 \mathrm{C}$ ). In both strains, $\mathrm{NAD}^{+}$and $\mathrm{NADH}$ concentrations decreased in cell growth phases and remained constant in non-growth phases. NOX expression in JC-12 yodC resulted in a relatively higher level of $\mathrm{NAD}^{+}$and NADH pools when compared with strain JC-12p261 (Figure $2 \mathrm{C}, \mathrm{D}$ ). Meanwhile, no obvious difference in the $\mathrm{NAD}^{+} / \mathrm{NADH}$ ratio of these two strains was observed (Figure 2E). These results indicate that the intracellular redox balance in JC-12 yodC was not disturbed, which could explain why its cell growth was not obviously affected. The "extra" NAD regenerated in JC- $12_{\text {yodC }}$ by NOX could be utilized in the NAD ${ }^{+}$consumed pathway of sterols metabolic flux to improve ADD yield, which could explain why NOX expression has no remarkable effect on the $\mathrm{NAD}^{+} / \mathrm{NADH}$ ratio.

During the fermentation, the intracellular NADH and $\mathrm{NAD}^{+}$concentrations are important reductants and oxidants for cellular metabolism, and they are constantly regenerated to realize redox equilibrium for continued anabolism and catabolism [16]. However, the sterol transformation pathway caused a decrease in $\mathrm{NAD}^{+}$concentration and availability. In this study, we firstly introduced the NOX from B. subtilis to improve the $\mathrm{NAD}^{+}$availability and to drive the metabolic flux of the sterol transformation pathway. As expected, the final ADD production was further improved. Similar results were shown when regulating the intracellular $\mathrm{NADP}^{+}$and NADPH concentrations, the bio-production of testosterone was improved significantly [3]. By moderate-expressing NOX in B. subtilis, the NADH-dependent metabolic pathway was rebalanced and the acetoin production was improved [21]. Su et al. also reported that the $\mathrm{NAD}^{+} / \mathrm{NADH}$ ratio was an important factor and the expression of NOX could improve ADD yield [12]. This result indicates that the balance of intracellular $\mathrm{NAD}^{+}$and $\mathrm{NADH}$ concentrations was important during the sterol transformation. 


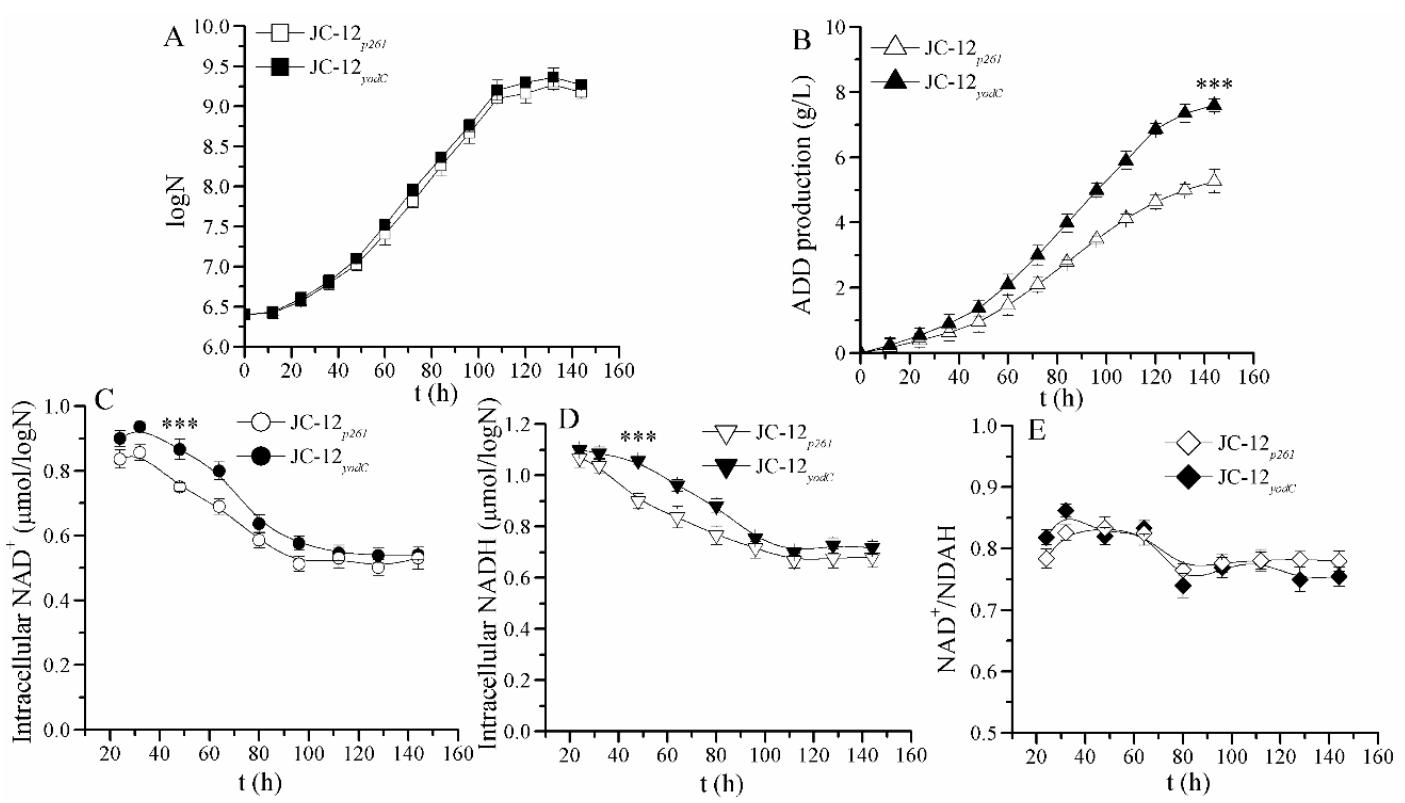

Figure 2. Time profiles of ADD fermentation and intracellular NADH and $\mathrm{NAD}^{+}$concentrations by strain JC-12 261 (hollow) and strain JC-12 yodC (solid). (A) the cell growth; (B) the ADD production, (C) intracellular $\mathrm{NAD}^{+}$concentration; (D) intracellular NADH concentration; (E) intracellular $\mathrm{NAD}^{+} / \mathrm{NADH}$ ratio. $\mathrm{N}$, the number of $\mathrm{CFU}$ (colony forming units) per $\mathrm{mL}$ of culture broth. An amount of $20 \mathrm{~g} / \mathrm{L}$ phytosterol was used as a substrate to carry out the fermentation. The results are shown in biological triplicate. One-way ANOVA was used to examine the mean differences between the points of the data groups. ${ }^{* *} p<0.001$. The statistical significance has been found between the two analyzed strains. Error bars show standard deviations.

2.2. The Over-Expression of Catalase Eliminated the Toxic Effect of $\mathrm{H}_{2} \mathrm{O}_{2}$ Accumulation on Strain Growth and ADD Production

The strong oxidizer $\mathrm{H}_{2} \mathrm{O}_{2}$ is generated during the regeneration of flavin adenine dinucleotide (FAD) in the phytosterol transformation process. $\mathrm{H}_{2} \mathrm{O}_{2}$ could damage different cellular components, such as proteins, DNA and lipids [22], which may result in a potentially inhibited cell growth and ADD yield. Thus, catalase was over-expressed to increase the production of ADD by eliminating the toxic effects of $\mathrm{H}_{2} \mathrm{O}_{2}$. The successful construction of recombinant strain JC- $12_{\text {yodC-katA }}$ was verified by plasmid extraction and gene sequencing.

In order to confirm the successful expression of NOX and catalase in recombinant strain JC-12 yodC-katA, enzyme activities were analyzed and the results are shown in Table 1 . Strain JC-12 yodC showed the NOX activity of $337.2 \mathrm{mU} / \mathrm{mg}$, which was about 13-fold of that of JC-12p261, while strain JC-12 yodC-katA showed the catalase activity of $235 \mathrm{U} / \mathrm{mg}$, which was 8.7 -fold of JC-12 2261 . Moreover, the

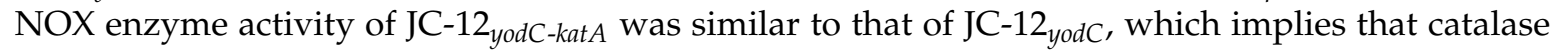
expression has no effect on NOX activity. The enzymatic activity analysis showed that NOX and catalase successfully co-expressed in M. neoaurum JC-12.

We also measured the extracellular $\mathrm{H}_{2} \mathrm{O}_{2}$ concentrations and intracellular reactive oxygen species (ROS) levels. As shown in Figure 3, compared with strain JC-12 yodC-katA, the extracellular $\mathrm{H}_{2} \mathrm{O}_{2}$ concentrations and intracellular ROS levels of strain JC-12 yodC were increased during the phytosterol conversion process, which resulted in the stagnation of both cell growth and ADD yield (Figure 3C,D). This was mainly because during the sterol conversion process, the intracellular FAD was regenerated. As a result of FAD regeneration, $\mathrm{H}_{2} \mathrm{O}_{2}$, which is toxic for diverse cellular components, was generated and increased. On the contrary, both the biomass and ADD production of recombinant strain JC- $12_{\text {yodC-kat } A}$ was higher than that of strain JC-12 yod $_{\text {, }}$ and the final ADD yield reached a maximum of $9.36 \mathrm{~g} / \mathrm{L}$ with an increase of $24 \%$ (Figure $3 \mathrm{~A}, \mathrm{~B}$ ). This was mainly due to the fact that catalase was over-expressed in JC-12 yodC-kat $A$, which could simultaneously scavenge the generated $\mathrm{H}_{2} \mathrm{O}_{2}$ and eliminate its toxic effects 
on the diverse cellular components and sterol transformation. Therefore, over-expression of catalase was beneficial for cell growth and ADD yield.

Table 1. Specific enzyme activities of NOX and catalase in recombinant M. neoaurum strains.

\begin{tabular}{ccc}
\hline \multirow{2}{*}{ Strains } & \multicolumn{2}{c}{ Enzyme Activity * } \\
\cline { 2 - 3 } & NOX (mU/mg) & Catalase (U/mg) \\
\hline JC-12 p $261_{\text {JC-12 }}^{\text {yodC }}$ & $25.6 \pm 1.5$ & $27 \pm 3$ \\
JC-12 yodC-katA & $337.2 \pm 9.6$ & $23 \pm 5$ \\
\hline
\end{tabular}

Note: The results are shown in biological triplicate. ${ }^{*}$ One unit of NOX enzyme activity is defined as the amount of enzyme that produced $1 \mu \mathrm{mol}$ of $\mathrm{NAD}^{+}$per minute at $30^{\circ} \mathrm{C}$ and $\mathrm{pH} 7.0$. One unit of catalase enzyme activity is defined as the decomposition of $1 \mu \mathrm{mol} \mathrm{H}_{2} \mathrm{O}_{2}\left(\varepsilon_{240}=43.6 \times 10^{3} / \mathrm{cm} / \mathrm{M}\right)$ per min at $30^{\circ} \mathrm{C}$ and $\mathrm{pH} 7.0$.
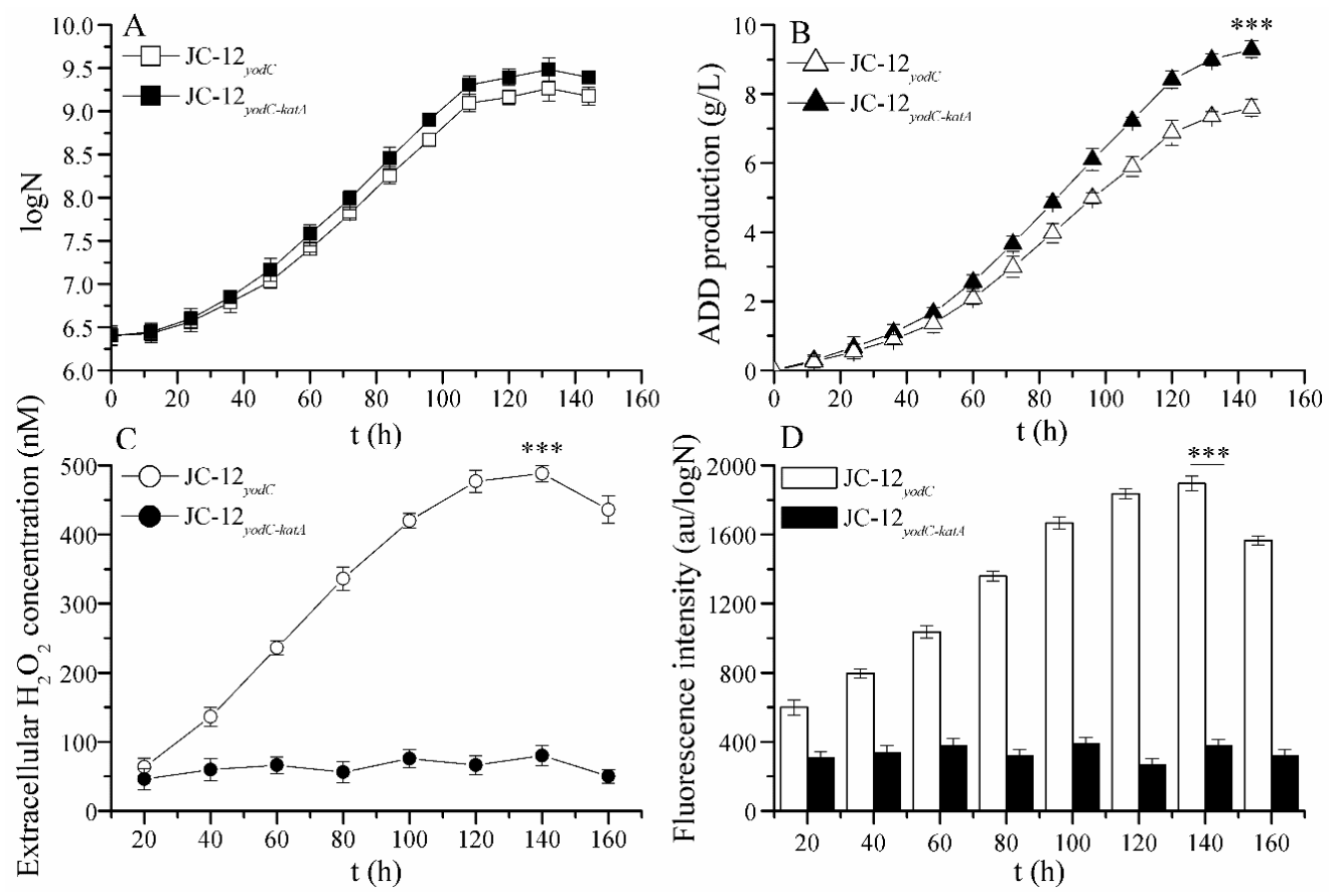

Figure 3. Time profiles of ADD fermentation and the extracellular $\mathrm{H}_{2} \mathrm{O}_{2}$ concentrations and intracellular reactive oxygen species (ROS) levels by strain JC-12 yodC (hollow) and strain JC-12 yodC-katA (solid). (A) the cell growth; (B) the ADD production, (C) extracellular $\mathrm{H}_{2} \mathrm{O}_{2}$ concentration; (D) intracellular ROS levels. $\mathrm{N}$, the number of CFU (colony forming units) per $\mathrm{mL}$ of culture broth. $20 \mathrm{~g} / \mathrm{L}$ phytosterol was used as a substrate to carry out the fermentation. The results are shown in biological triplicate. One-way ANOVA was used to examine the mean differences between the points of the data groups. *** $p<0.001$. The statistical significance has been found between the two analyzed strains. Error bars showed standard deviations.

In the sterol transformation process, $\mathrm{H}_{2} \mathrm{O}_{2}$ was produced within the FAD regeneration system. The accumulation of high $\mathrm{H}_{2} \mathrm{O}_{2}$ concentration has the potential to damage diverse cellular components and further lead to toxic effects on cell growth and ADD production. This outcome was possibly due to the lack of catalase and peroxidase activity for this strain, causing an inability to eliminate $\mathrm{H}_{2} \mathrm{O}_{2}$ in a timely fashion and allowing for an easy accumulation to a high concentration. High $\mathrm{H}_{2} \mathrm{O}_{2}$ concentration resulted in substantial damage to the proteins and DNA [23], which resulted in the inhibition of cell growth and enzyme activities. The over-expression of catalase could effectively eliminate the toxic effect of the generated $\mathrm{H}_{2} \mathrm{O}_{2}$, which when tested resulted in higher biomass and ADD production. Therefore, the catalase expression is needed for achieving high sterol conversion efficiency. These results indicate that the regulation of the intracellular $\mathrm{NAD}^{+} / \mathrm{NADH}$ and $\mathrm{H}_{2} \mathrm{O}_{2}$ level 
is a promising way to enhance the transformation efficiency of low-cost sterols to valuable steroid precursors in the pharmaceutical industry.

In order to further verify the capability of strain JC-12 yodC-katA $_{\text {on }}$ industry scale, a $5 \mathrm{~L}$ bioreactor was used to evaluate its performance with $20 \mathrm{~g} / \mathrm{L}$ phytosterol. As shown in Figure 4C, the final ADD production of JC-12 yodC-katA reached $9.66 \mathrm{~g} / \mathrm{L}$ at $144 \mathrm{~h}$, which was 1.8 -fold of the ADD production $(5.36 \mathrm{~g} / \mathrm{L})$ by the original JC- $12_{p 261}$. All of the results confirm that the regulation of the intracellular $\mathrm{NAD}^{+} / \mathrm{NADH}$ and $\mathrm{H}_{2} \mathrm{O}_{2}$ level could be an effective way to improve sterol transformation efficiency and the production of steroid intermediates.
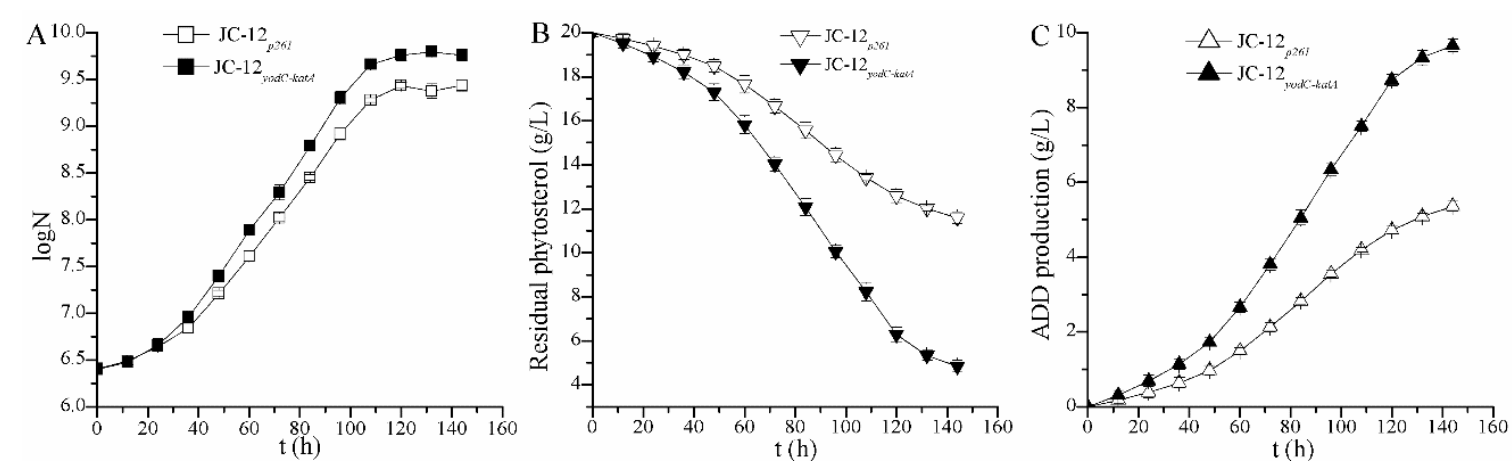

Figure 4. Time profiles of ADD fermentation by strain JC-12 $2_{p 261}$ (hollow) and the recombinant strain JC-12 yodC-katA (solid) in a $5 \mathrm{~L}$ fermentor. (A) the cell growth; (B) the residual phytosterol; (C) the ADD production. $\mathrm{N}$, the number of CFU (colony forming units) per mL of culture broth. $20 \mathrm{~g} / \mathrm{L}$ phytosterol was used as a substrate to carry out the fermentation. The results are shown in biological triplicate. Error bars showed standard deviations.

\section{Materials and Methods}

\subsection{Strains and Culture Conditions}

Table 2 shows the primers, plasmids and strains used in our study. Strain E. coli was cultured in Luria-Bertain (LB) medium and strain M. neoaurum was cultured in seed medium including $10 \mathrm{~g} / \mathrm{L}$ glucose, $10 \mathrm{~g} / \mathrm{L}$ peptone, $6 \mathrm{~g} / \mathrm{L}$ beef extract, $10 \mathrm{~g} / \mathrm{L} \mathrm{NaCl}$ at $\mathrm{pH}$ 7.5. The fermentation medium contained $20 \mathrm{~g} / \mathrm{L}$ glucose, $10 \mathrm{~g} / \mathrm{L}$ peptone, $6 \mathrm{~g} / \mathrm{L}$ beef extract, $3 \mathrm{~g} / \mathrm{L} \mathrm{K}{ }_{2} \mathrm{HPO}_{4}, 0.5 \mathrm{~g} / \mathrm{L} \mathrm{MgSO} \cdot 7 \mathrm{H}_{2} \mathrm{O}$, $5 \times 10^{-4} \mathrm{~g} / \mathrm{L} \mathrm{MnCl}_{2} \cdot 4 \mathrm{H}_{2} \mathrm{O}$ at $\mathrm{pH} 7.5$ [13].Hydroxymethyl- $\beta$-cyclodextrin (HP- $\beta$-CD) was added to improve phytosterol solubility and the mass ratio of sterol to HP- $\beta$-CD was 1:3 $(w / w)$. The fermentation was carried out in $50 \mathrm{~mL}$ shake flasks at $\mathrm{pH} 7.5$ and $30^{\circ} \mathrm{C}$ with $160 \mathrm{rpm}$ agitation speed. The scale-up fermentation was carried out using a $5 \mathrm{~L}$ bioreactor with $400 \mathrm{rpm}$ agitation speed, $1 \mathrm{vvm}$ ventilation at $\mathrm{pH} 7.5$ and $30^{\circ} \mathrm{C}$. Corresponding antibiotics were added when needed. 
Table 2. Primers, plasmids and strains used in this study.

\begin{tabular}{|c|c|c|}
\hline Strains/Plasmids/Primers & Description & Sources \\
\hline \multicolumn{3}{|c|}{ Strains } \\
\hline \multicolumn{3}{|l|}{ Escherichia coli } \\
\hline JM109 & General host for gene cloning & Invitrogen, (Carlsbad, CA, USA) \\
\hline \multicolumn{3}{|l|}{ Mycobacterium neoaurum } \\
\hline JC-12 & Wild type strain, converting sterols to ADD with small amount of AD & Lab storage, (Wuxi, China) \\
\hline $\mathrm{JC}-12_{p 261}$ & JC-12 harboring empty plasmid pMV261 & This study \\
\hline JC- $12_{\text {yodC }}$ & NOX over-expressed strain of JC-12, harboring plasmid pMV261-yodC & This study \\
\hline JC-12 yodC-katA & Catalase over-expressed strain of JC-12 yodC, harboring plasmid pMV261-yodC-kat $A$ & This study \\
\hline \multicolumn{3}{|l|}{ Plasmids } \\
\hline pMD18-T & E. coli clone vector; $\mathrm{Amp}^{\mathrm{R}}$ & Novagen, (Madison, WI, USA) \\
\hline pMV261 & Shuttle vector of E. coli and mycobacterium, carrying the heat shock promoter $h s p 60 ; \mathrm{Kan}^{\mathrm{R}}$ & R. Jacobs Jr. \\
\hline pMV261-yodC & pMV261 carrying yodC gene; $\operatorname{Kan}^{\mathrm{R}}$ & This study \\
\hline pMV261-yodC-katA & pMV261-yodC carrying kat $A$ gene with its SD sequence inserted after yodC; $\operatorname{Kan}^{\mathrm{R}}$ & This study \\
\hline \multicolumn{3}{|l|}{ Primers } \\
\hline yodC-f & CGGGATCCATGACGAATACTCTGGATG & This study \\
\hline yodC-r & CGGAATTCTTACAGCCAAGTTGATAC & This study \\
\hline katA-SD-f & ACGAAGCTTaagaaggagatataATGCGCGAAAGGAACAGCCC & This study \\
\hline kat $A-\mathrm{r}$ & ACGAAGCTTCTACTTGACGGCCGCCTC & This study \\
\hline
\end{tabular}




\subsection{Over-Expression of NOX and Catalase in M. Neoaurum JC-12}

We used pMV261 as an expression vector in M. neoaurum JC-12 to express NOX and catalase. The yodC gene from B. subtilis (Gene ID: 939506) was amplified using primers yodC-f/yodC-r and inserted to $B a m \mathrm{H}$ I/EcoR I sites to create recombinant plasmid pMV261-yodC. The strain was then transformed to obtain recombinant strain JC-12 $2_{\text {odC }}$. To augment the catalase expression in JC-12 yodC, the kat $A$ gene from M. neoaurum (Gene ID: 674842736) was amplified by primers katA-SD-f/katA-r. The fragment of kat $A$ gene was then inserted into pMV261-yodC at Hind III site to construct pMV261-yodC-katA, and the plasmid was converted into JC-12 yodC to create strain JC-12 yodC-katA .

\subsection{NOX and Catalase Enzyme Activity Assays}

NOX activity was determined according to a previous study [21], and one unit was defined as the amount of enzyme that produced $1 \mu \mathrm{mol}$ of $\mathrm{NAD}^{+}$per minute at $\mathrm{pH} 7.0$ and $30^{\circ} \mathrm{C}$. Determination of $\mathrm{NADH}$ and $\mathrm{NAD}^{+}$intracellular concentrations was according to the operating manual of Amplite Fluorimetric $\mathrm{NAD}^{+} / \mathrm{NADH}$ Ratio Assay Kit (Sunnyvale, CA, USA) [24].

Catalase activity was detected as per a previous work [19], and one unit was defined as the decomposition of $1 \mu \mathrm{mol} \mathrm{H}_{2} \mathrm{O}_{2}\left(\varepsilon_{240}=43.6 \times 10^{3} / \mathrm{cm} / \mathrm{M}\right)$ per min at $\mathrm{pH} 7.0$ and $30^{\circ} \mathrm{C}$. Intracellular reactive oxygen species (ROS) levels were detected using the fluorogenic probe $2^{\prime}, 7^{\prime}$-dichlorofluorescein diacetate (DCFH-DA) described previously $[25,26]$. Extracellular $\mathrm{H}_{2} \mathrm{O}_{2}$ concentrations were measured according to the operating manual of Amplex Red Hydrogen Peroxide/Peroxidase Assay Kit (Waltham, MA, USA) [14].

\subsection{Analytical Methods}

A $1 \mathrm{~mL}$ sample from the culture broth wasextracted with $4 \mathrm{~mL}$ ethyl acetate. Then, the supernatant was detected after centrifugation by high performance liquid chromatography (HPLC, Palo Alto, CA, USA) equipped with a C18 column (Diamonsil ${ }^{\circledR} \mathrm{C} 18,5 \mu \mathrm{m}$ particles, $250 \mathrm{~mm} \times 4.6 \mathrm{~mm}$ ) and a UV/visible detector. The mobile phase contains water and methanol of 30:70 (v/v) and ADD was measured at $254 \mathrm{~nm}$ with a column temperature of $30^{\circ} \mathrm{C}$ and $1 \mathrm{~mL} / \mathrm{min}$ flow rate [27]. The biomass was shown as CFU number per $\mathrm{mL}$ of fermentation broth during cultivation [28]. Sterol determination was carried out using gas chromatography (GC) [29].

\section{Conclusions}

In this study, in order to balance the cell intracellular environment during phytosterol transformation, we firstly introduced a water-forming NOX from B. subtilis to increase the NAD ${ }^{+}$ availability. Then, the catalase was over-expressed to eliminate the toxic effects of the $\mathrm{H}_{2} \mathrm{O}_{2}$ generated during the FAD regeneration system. The final ADD production using a $5 \mathrm{~L}$ fermentor reached $9.66 \mathrm{~g} / \mathrm{L}$ with an increase of $80 \%$. This work provides new insight to improve microbial cells for efficiently converting sterols to other valuable steroid metabolites in the pharmaceutical industry.

Author Contributions: Conceptualization, Z.R.; investigation, M.S., Y.L. and Y.Z.; data curation, T.Y. and M.X.; formal analysis, M.S., Y.Z., Y.L. and X.Z.; writing—original draft, M.S.

Funding: This research was funded by the National Natural Science Foundation of China (31700041 and 31570085), the National Key Research and Development Program of China (2018YFA0900304), National First-Class Discipline Program of Light Industry Technology and Engineering (LITE 2018-06) and the 111 Project (111-2-06).

Acknowledgments: We sincerely appreciate W. R. Jacobs, Jr. (Howard Hughes Medical Institute, USA) for providing plasmids pMV261.

Conflicts of Interest: The authors declare no conflict of interest. 


\section{Abbreviations}

$\begin{array}{ll}\text { AD } & \text { 4-androstene-3,17-dione } \\ \text { ADD } & \text { androst-1,4-diene-3,17-dione } \\ \text { CFU } & \text { colony forming units } \\ \mathrm{HP}-\beta-C D & \text { hydroxymethyl- } \beta \text {-cyclodextrin } \\ \mathrm{H}_{2} \mathrm{O}_{2} & \text { hydrogen peroxide } \\ \text { ROS } & \text { reactive oxygen species } \\ \text { NOX } & \text { NADH oxidase } \\ \text { DCFH-DA } & 2^{\prime}, 7^{\prime} \text {-dichlorofluorescein diacetate } \\ \text { GC } & \text { gas chromatography } \\ \text { HPLC } & \text { high performance liquid chromatography }\end{array}$

\section{References}

1. Donova, M. Microbiotechnologies for steroid production. Microbiol. Aust. 2018, 39, 126-129. [CrossRef]

2. Malaviya, A.; Gomes, J. Androstenedione production by biotransformation of phytosterols. Bioresour. Technol. 2008, 99, 6725-6737. [CrossRef] [PubMed]

3. Shao, M.L.; Zhang, X.; Rao, Z.M.; Xu, M.J.; Yang, T.W.; Li, H.; Xu, Z.H.; Yang, S.T. Efficient testosterone production by engineered Pichia pastoris co-expressing human $17 \beta$-hydroxysteroid dehydrogenase type 3 and Saccharomyces cerevisiae glucose 6-phosphate dehydrogenase with NADPH regeneration. Green Chem. 2016, 18, 1774-1784. [CrossRef]

4. Bao, T.; Zhang, X.; Rao, Z.M.; Zhao, X.J.; Zhang, R.Z.; Yang, T.W.; Xu, Z.H.; Yang, S.T. Efficient whole-cell biocatalyst for acetoin production with $\mathrm{NAD}^{+}$regeneration system through homologous co-expression of 2,3-butanediol dehydrogenase and NADH oxidase in engineered Bacillus subtilis. PLoS ONE 2014, 9, e102951. [CrossRef]

5. Donova, M.V.; Egorova, O.V. Microbial steroid transformations: Current state and prospects. Appl. Microbiol. Biotechnol. 2012, 94, 1423-1447. [CrossRef]

6. Josefsen, K.D.; Nordborg, A.; Sletta, H. Bioconversion of Phytosterols into Androstenedione by Mycobacterium. In Microbial Steroids; Springer: New York, NY, USA, 2017; pp. 177-197.

7. Van der Geize, R.; Yam, K.; Heuser, T.; Wilbrink, M.H.; Hara, H.; Anderton, M.C.; Sim, E.; Dijkhuizen, L.; Davies, J.E.; Mohn, W.W.; et al. A gene cluster encoding cholesterol catabolism in a soil actinomycete provides insight into Mycobacterium tuberculosis survival in macrophages. Proc. Natl. Acad. Sci. USA 2007, 104, 1947-1952. [CrossRef]

8. Fernández-Cabezón, L.; Galán, B.; García, J.L. New insights on steroid biotechnology. Front. Microbiol. 2018, 9, 958. [CrossRef]

9. Wei, W.; Wang, F.Q.; Fan, S.Y.; Wei, D.Z. Inactivation and augmentation of the primary 3-ketosteroid- $\Delta^{1}$-dehydrogenase in Mycobacterium neoaurum NwIB-01: Biotransformation of soybean phytosterols to 4-androstene-3,17-dione or 1,4-androstadiene-3,17-dione. Appl. Environ. Microbiol. 2010, 76, 4578-4582. [CrossRef]

10. Yao, K.; Wang, F.Q.; Zhang, H.C.; Wei, D.Z. Identification and engineering of cholesterol oxidases involved in the initial step of sterols catabolism in Mycobacterium neoaurum. Metab. Eng. 2013, 15, 75-87. [CrossRef]

11. Wei, W.; Fan, S.Y.; Wang, F.Q.; Wei, D.Z. Accumulation of androstadiene-dione by overexpression of heterologous 3-ketosteroid $\Delta 1$-dehydrogenase in Mycobacterium neoaurum NwIB-01. World J. Microbiol. Biotechnol. 2014, 30, 1947-1954. [CrossRef]

12. Su, L.; Shen, Y.; Zhang, W.; Gao, T.; Shang, Z.; Wang, M. Cofactor engineering to regulate NAD+/NADH ratio with its application to phytosterols biotransformation. Microb. Cell Fact. 2017, 16, 182. [CrossRef] [PubMed]

13. Shao, M.; Zhang, X.; Rao, Z.; Xu, M.; Yang, T.; Xu, Z.; Yang, S. Identification of steroid C27 monooxygenase isoenzymes involved in sterol catabolism and stepwise pathway engineering of Mycobacterium neoaurum for improved androst-1,4-diene-3,17-dione production. J. Ind. Microbiol. Biotechnol. 2019, 46, 635-647. [CrossRef] [PubMed]

14. Man, Z.; Rao, Z.; Xu, M.; Guo, J.; Yang, T.; Zhang, X.; Xu, Z. Improvement of the intracellular environment for enhancing L-arginine production of Corynebacterium glutamicum by inactivation of $\mathrm{H} 2 \mathrm{O} 2$-forming flavin reductases and optimization of ATP supply. Metab. Eng. 2016, 38, 310-321. [CrossRef] [PubMed] 
15. Angermayr, S.A.; Rovira, A.G.; Hellingwerf, K.J. Metabolic engineering of cyanobacteria for the synthesis of commodity products. Trends Biotechnol. 2015, 33, 352-361. [CrossRef] [PubMed]

16. Balzer, G.J.; Thakker, C.; Bennett, G.N.; San, K.-Y. Metabolic engineering of Escherichia coli to minimize byproduct formate and improving succinate productivity through increasing NADH availability by heterologous expression of NAD+-dependent formate dehydrogenase. Metab. Eng. 2013, 20, 1-8. [CrossRef] [PubMed]

17. Bao, T.; Zhang, X.; Zhao, X.; Rao, Z.; Yang, T.; Yang, S. Regulation of the NADH pool and NADH/NADPH ratio redistributes acetoin and 2,3-butanediol proportion in Bacillus subtilis. Biochem. J. 2015, 10, 1298-1306.

18. Szentirmai, A. Microbial physiology of sidechain degradation of sterols. J. Ind. Microbiol. Biotechnol. 1990, 6, 101-115. [CrossRef]

19. Shao, M.; Sha, Z.; Zhang, X.; Rao, Z.; Xu, M.; Yang, T.; Xu, Z.; Yang, S. Efficient androst-1,4-diene-3,17-dione production by co-expressing 3-ketosteroid- $\Delta 1$-dehydrogenase and catalase in Bacillus subtilis. J. Appl. Microbiol. 2017, 122, 119-128. [CrossRef]

20. Shao, M.L.; Zhang, X.; Rao, Z.M.; Xu, M.; Yang, T.; Li, H.; Xu, Z.; Yang, S. A mutant form of 3-ketosteroid- $\Delta$ 1-dehydrogenase gives altered androst-1,4-diene-3, 17-dione/androst-4-ene-3,17-dione molar ratios in steroid biotransformations by Mycobacterium neoaurum ST-095. J. Ind. Microbiol. Biotechnol. 2016, 43, 691-701. [CrossRef]

21. Zhang, X.; Zhang, R.Z.; Bao, T.; Rao, Z.M.; Yang, T.W.; Xu, M.J.; Xu, Z.H.; Li, H.Z.; Yang, S.T. The rebalanced pathway significantly enhances acetoin production by disruption of acetoin reductase gene and moderate-expression of a new water-forming NADH oxidase in Bacillus subtilis. Metab. Eng. 2014, 23, 34-41. [CrossRef]

22. Ezraty, B.; Gennaris, A.; Barras, F.; Collet, J.F. Oxidative stress, protein damage and repair in bacteria. Nat. Rev. Microbiol. 2017, 15, 385. [CrossRef] [PubMed]

23. Liu, Y.; Imlay, J.A. Cell death from antibiotics without the involvement of reactive oxygen species. Science 2013, 339, 1210-1213. [CrossRef] [PubMed]

24. O’Donnell, J.M.; Kudej, R.K.; LaNoue, K.F.; Vatner, S.F.; Lewandowski, E.D. Limited transfer of cytosolic NADH into mitochondria at high cardiac workload. Am. J. Physiol. Heart Circ. Physiol. 2004, 286, H2237-H2242. [CrossRef] [PubMed]

25. Si, M.R.; Zhang, L.; Yang, Z.F.; Xu, Y.X.; Liu, Y.B.; Jiang, C.Y.; Wang, Y.; Shen, X.H.; Liu, S.J. $\mathrm{NrdH}$ redoxin enhances resistance to multiple oxidative stresses by acting as a peroxidase cofactor in Corynebacterium glutamicum. Appl. Environ. Microbiol. 2014, 80, 1750-1762. [CrossRef] [PubMed]

26. Si, M.; Xu, Y.; Wang, T.; Long, M.; Ding, W.; Chen, C.; Guan, X.; Liu, Y.; Wang, Y.; Shen, X. Functional characterization of a mycothiol peroxidase in Corynebacterium glutamicum that uses both mycoredoxin and thioredoxin reducing systems in the response to oxidative stress. Biochem. J. 2015, 469, 45-57. [CrossRef]

27. Zhang, W.Q.; Shao, M.L.; Rao, Z.M.; Xu, M.J.; Zhang, X.; Yang, T.W.; Li, H.; Xu, Z.H. Bioconversion of 4-androstene-3,17-dione to androst-1,4-diene-3,17-dione by recombinant Bacillus subtilis expressing ksdd gene encoding 3-ketosteroid- $\Delta^{1}$-dehydrogenase from Mycobacterium neoaurum JC-12. J. Steroid Biochem. Mol. Biol. 2013, 135, 36-42. [CrossRef]

28. Molchanova, M.A.; Andryushina, V.A.; Savinova, T.S.; Stytsenko, T.S.; Rodina, N.V.; Voishvillo, N.E. Preparation of androsta-1,4-diene-3,17-dione from sterols using Mycobacterium neoaurum VKPM Ac-1656 strain. Russ. J. Bioorganic. Chem. 2007, 33, 354-358. [CrossRef]

29. Duong, S.; Strobel, N.; Buddhadasa, S.; Stockham, K.; Auldist, M.; Wales, B.; Orbell, J.; Cran, M. Rapid measurement of phytosterols in fortified food using gas chromatography with flame ionization detection. Food Chem. 2016, 211, 570-576. [CrossRef]

(C) 2019 by the authors. Licensee MDPI, Basel, Switzerland. This article is an open access article distributed under the terms and conditions of the Creative Commons Attribution (CC BY) license (http://creativecommons.org/licenses/by/4.0/). 